\title{
THE MINUTE BOOK OF THE CAPE TOWN BRANCH OF THE CLASSICAL ASSOCIATION OF SOUTH AFRICA, 1927-1940
}

\author{
J Murray (University of Cape Town) ${ }^{1}$
}

\begin{abstract}
This article surveys the contents of archival material found in the manuscript and archives section of the Special Collections of the University of Cape Town Libraries. In particular, it scrutinises the activities recorded in the Minute Book of the Cape Town Branch of the Classical Association of South Africa, 1927-1940. The details found in the Minute Book shed valuable light on the teaching and research of classical antiquity in South Africa in the early part of the twentieth century, illuminating a lesser-known period of the history of the Classical Association of South Africa.
\end{abstract}

Keywords: History of Classical Scholarship; Classical education; Classical Association of South Africa; South African history; intellectual history.

In his record of the Classical Association of South Africa, 1908-1956, William Henderson noted that, 'There was also a CASA during the years 1927-1956, until now considered the "first", but henceforth to be regarded as the "second". Very little has been written about and not much interest shown in this second association, probably because of lack of information, most of it buried in archives or lost'. ${ }^{2}$ More information is to be found in the Minute Book of the Cape Town Branch of the Classical Association of South Africa, covering the years 1927 to 1940, housed in the manuscripts and archives section of the Special Collections of the University of Cape Town Libraries (file BCS20). The large foolscap-size Minute Book can be divided into two sections, the first taken up with an alphabetized index of, presumably, the names of the members (along with their addresses) of the Cape Town branch, followed by a second section, which provides a yearly account of meetings held, interspersed with newspaper clippings relevant

I am grateful to David Wardle and the journal's anonymous referees for their helpful comments on this article; I also thank Paul Murray (archivist at Bishops Diocesan College) and Clive Kirkwood (Special Collections, University of Cape Town Libraries) for their assistance.

2 Henderson 2013:123. Basic outlines of the activities of the Classical Association in South Africa at this time, as well as the publication of selected papers presented, are to be found in first (1927-29) and second (1929-31) issues of the Proceedings and Selected Papers of the Classical Association of South Africa. The best survey of classical scholarship and teaching in the Cape during this period is still Smuts 1960:7-31. 
to the various gatherings. ${ }^{3}$ On the title page of the book, written by hand, is the following, 'Classical Association of South Africa Capetown Branch'. Before the first handwritten entry, a newspaper clipping from the Cape Times for 25 April 1927 is included, with the heading 'S African Classical Association. Cape Town local centre formed'. The report briefly sketches the formation of the national Association earlier that year on 26 March, and then outlines the activities of the branch meeting in April:

At a meeting held at the University of Cape Town on Saturday it was agreed to form a Local Centre of the Association. There was a representative gathering of the University staff present, also a number of teachers and students. It was agreed that the affairs of the Cape Town Local Centre should be under the control of a committee consisting of a President, two honorary secretaries, an honorary treasurer and two ordinary members. Professor W Ritchie was elected president; Mr B Farrington (academic secretary), Rev A Fox (school secretary), Professor T Le Roux (treasurer), Miss King (Wynberg Girls' High School, representing the Schools), and Mr D'Ewes (representing students) were elected to the committee. Following the rules of the Classical Association of South Africa it was decided to admit two classes of members, (a) ordinary members - annual subscription 5s. - and (b) junior or student members - annual subscription $3 \mathrm{~s}{ }^{4}$

Within the membership roll, certain names have been crossed out — presumably upon the death of the member concerned.

4 In the year 1927, William Ritchie was Professor of Latin in the Classics Department at the University of Cape Town (The Chairs of Latin and Greek were separated in 1903, and Ritchie chose Latin over Greek, claiming it would bring him into closer contact with the students; these separate departments were again joined to form the 'Classics Department' in 1923). After a short stint as lecturer in Classics and English at the Grey Institute in Port Elizabeth (1879-1882) after his arrival in southern Africa, he was appointed to the South African College (renamed the 'University of Cape Town' in 1918) where he remained until his retirement in 1929. Born 12 October 1854 in Peterhead, Scotland, Ritchie was the second youngest child of John Ritchie and Jane Robertson. He married Emily Kate Jerome, with whom he fathered four children. For his schooling, he attended Peterhead Academy, where in 1869 he won a bursary to Aberdeen University, obtaining the MA in 1873 with First Class Honours in Classics and winning the Seafield Gold Medal in Latin. He then continued his studies at Oriel College, Oxford (in the company of Cecil John Rhodes), achieving Firsts in both Mods (1875) and Greats (1877). He subsequently spent part of the following year abroad at Göttingen University before returning to Oxford, where he gave private tuition until he emigrated to South Africa. Ritchie acted as secretary to the College Senate, was a member of the Council of the University of the Cape of Good Hope, President of 
The first handwritten entry is laid out under the title 'General Meeting', and dated ' $23^{\text {rd }}$ April, 1927'. The report indicates that the meeting was held at the 'University Buildings, Queen Victoria St', noting that 27 persons were present, of whom 24 enrolled their names as prospective members: Mr J Allan, principal SAC High School, Principal J Carruthers Beattie, UCT, Prof John Clark, UCT, Mr E B de Beer, St George's Grammar School, Mr D R D'Ewes, UCT, Mr B Farrington, UCT, Rev Adam Fox, Diocesan College, Rondebosch, Mr R C Langdon-Davies, Diocesan College, Rondebosch, J Longwill, Prof Le Roux, UCT, Miss S Lewis, UCT, Mr E N Munday, Prof R D Nauta, UCT, Mr J P Niehaus, UCT, Prof W Ritchie, UCT, Mr P W M Rogers, SAC High School, Dr W Rollo, UCT, Mr W A Russell, 'Tempe', Kensington Crescent, Miss F S Stewart, UCT, Mr D C M v d Merwe, UCT, Mr H E Viljoen, 6 Camp St, Mr J P Visser, UCT, Mr J T Wilson, SAC HS, Prof J Kerr Wylie, UCT.

Professor Ritchie chaired the meeting in the absence of the Minister of Education, Dr Viljoen, with Dr Rollo proposing the formation of the Cape Town Branch as a local centre, and Mr Russell seconding the proposal. ${ }^{5} \mathrm{Next}$, the persons

Convocation, and Vice-Chancellor. Ritchie's magnum opus, and the work he is perhaps best known for, was his two volume history of the South African College (published in 1918), but he was also a keen translator of classical texts, publishing two translations of Plautus (Trinummus, 'Half-a-crown' and Captivi, 'Prisoners of war', both in 1921) and the complete plays of Terence, translated into parallel English metres in 1927, the year that the records of the Minute Book begin. Ritchie's preface to the translation records that its genesis came from 'a proposed performance of one of Terence's plays by [his] students' and that the text was subsequently used 'in the illustration of metrical points in reading Terence in class'. This biographical sketch was produced from the information found in the notes left by F Smuts in a folder in the UCT Special Collections and Archives file labelled 'BUZV'. Further biographical details for Ritchie are found, where relevant, mentioned below.

5 Hendrik Geldenhuys Viljoen (not to be confused with his son, also a classicist and the minister of education, Gerrit Viljoen), was Professor of Greek at the University of Pretoria (Smuts 1960:27). William Rollo (1892-1960) joined UCT in 1926, becoming professor in 1935, and served the university until retirement in 1952. He trained in Classics at Glasgow University and completed his doctorate in Leiden in 1920, completing a second doctorate on the Basque dialect of Marquina also at Leiden in 1925 - a fascinating account of his fieldwork was recorded in his wife's diary, and published in Eggermont-Molenaa 2009:307-342; further biographical details are to be found in Smuts 1960:7-31. W A Russell was educated in Belfast and Cambridge and was headmaster of SACS from 1891-1901 (see Ritchie 1918:310), at which point he took up the position of assistant director of education in the Orange River Colony, a position he held from 1901-1903, being dismissed because of disagreements in policy with the director, E B Sargent (see Russell 1905). He produced The development of the art of language as exhibited in Latin and English in 1933 and reviewed a work on Latin syntax 
listed above in the Cape Times report were elected to office, and the Minute Book mentions that it was thought prudent that one of the secretaries should be elected to represent the university, while the other should represent the schools; and of the two additional members, one should be appointed from the staff of the secondary schools and the other from among the university students. It was also decided that the committee should arrange at least one public lecture per term, or one ordinary meeting at which a paper should be read, or a lecture given. Dr Rollo, as Secretary of the National Committee, was then called upon to give a report of the progress of the Association to date. Membership for 1927 is recorded at 36 members in total, with 22 ordinary members, and 14 student members. The General Meeting was followed, on the same day, by a Committee Meeting, at which it was decided that the first public lecture should take place in the third week of the following term (i.e. around 20 May), and that it should be a lecture on Pompeii by the President. It was also agreed that Mr Bourne should be asked to read a paper, early in June, at an ordinary meeting. Mr Farrington was charged to make the necessary arrangements. ${ }^{6}$

The first public meeting was held on 18 May 1927, in the University Buildings on Queen Victoria Street at 8pm. Professor William Ritchie lectured on Pompeii, and Professor Le Roux took charge of the lantern. ${ }^{7}$ There were about 150 people in attendance in the lecture room, which proved too small for the occasion. The Minute Book records, 'it was generally felt to be a most auspicious opening for the new society'. The committee met after the lecture, where the secretary noted that Miss King had declined to serve on the committee, and it was decided that they should approach Miss Smythe to fill the vacant place. The date of the next

for Classical Review (1909:65-71), where his position is given as 'Inspector of High Schools, Cape Colony'.

${ }^{6}$ Benjamin Farrington (1891-1974) joined the University of Cape Town in 1920. He remained at the university until 1935 when he moved first to Bristol for a year, and then took up the chair of Classics at the University College of Swansea (see Atkinson 2010:671-692, Atkinson 2014:170-184, and esp. Atkinson 2018:376-394). Arthur Henry Johnstone Bourne, MA (Cantab.), came to South Africa after a teaching stint at Trent College, Nottingham, first teaching at Dale College, King William's Town, then he became principal of the Public School in Mossel Bay, and finally was made headmaster of Kimberley Boys' High School from 1904-1917 (see Moult 1987:58-85). Bourne was replaced as headmaster by O J S Satchel, on whom, more below. Bourne produced a study of the educationalist and poet, William Archer Way (1869-1928), W A Way: Headmaster and poet (London, 1931) as well as for Maskew Miller's school textbook series, Synopsis of Latin syntax by practice (Cape Town, 1917).

7 Theo Le Roux, a former student of Victoria College (now Stellenbosch University), after completing a doctorate in Amsterdam in 1916, joined the University of Cape Town, being appointed as Professor of Greek in 1919 in the chair vacated by Prof C E Lewis. He remained at the university until his death in 1948 (see Smuts 1960:7-31). 
meeting was set for 8 June. On this date the first ordinary meeting of the society was held in the University Buildings, Queen Victoria Street, at $8 \mathrm{pm}$ Papers were presented by Mr A H J Bourne on Aeneid IV, and Dr W Rollo on the dating of the Laocoön sculpture group. Roughly 40 people attended the meeting. In August of that year (no date given), Prof T Le Roux gave a paper on the Acropolis to about 80 audience members, in September $\mathrm{Mr}$ W A Russell gave a lecture on the 'Nominative and accusative' as well as Mr B Farrington on 'A Cretan mystery of the XVI century'.

For the year 1928, the following committee was elected at the Annual General Meeting: Prof W Ritchie (President), Mr B Farrington and Rev A Fox (Honorary Secretaries), Prof T Le Roux (Treasurer), and Mr E N Munday and Mr R Whiteford (Committee Members). ${ }^{9}$ The minutes for 1927 were read and confirmed, as was the treasurer's statement — a balance of $£ 2.16$ was recorded with 27 full members and 2 student members. The opening meeting of the year took place on 4 April. Prof A E Snape read a paper on 'Roman Construction and Architecture and their Modern Influence', illustrated with lantern slides, attended by about 40 people. $^{10}$ The paper was subsequently published in full in the Cape Times. On 25 April Rev Adam Fox read a paper on 'The New Testament and its place among the Classics', with about 30 people in attendance. The Minute Book records that 'the paper was of unusual distinction, and was followed with the closest attention. It was the wish of the meeting that the paper should go forward for consideration by the publications committee'. ${ }^{11}$ The Honourable Patrick

8 This information is corroborated by the summary report for the Cape Town branch in the first issue of the Proceedings and Selected Papers of the Classical Association of South Africa (1927-1929:3).

9 E N Munday was Latin Master at Rondebosch Boys' High School from 1926-52. He graduated with a degree in Classics from Rhodes University in 1911 (Rondebosch Boys' High School Magazine, December 1954 No. 154:5-6). Robin Whiteford (19071986) was educated at SACS and the University of Cape Town, completing the BA, MA (with first class honours in Classics), as well BEd degrees. A popular teacher, he was appointed to a number of South Africa schools: Bishops, Kimberley Boys' High, Dale College, Muir College and SACS. Upon retirement from SACS in 1972 he joined the Classics department at UCT, where he was tasked with teaching beginner's Latin (see Baumbach 1987:48).

10 Alfred Ernest Snape (1881-1946) was Professor of Civil Engineering at UCT (Phillips 1993:75-9, 147).

11 The paper by Adam Fox (1883-1977) was published in the first issue of Proceedings and Selected Papers of the Classical Association of South Africa (1927-1929:31-42). Fox was educated at Winchester College, and University College, Oxford, where he graduated BA in 1906. He became schoolmaster at Lancing College, Warden of Radley College, relocating to South Africa for health reasons in 1925, where he took up the post of teacher at the Diocesan College, Rondebosch ('Bishops'). He was later to return to 
Duncan, read a paper on 'Plato's doctrine of reality' on 9 May. ${ }^{12}$ The entry records that this meeting, which numbered around 50 members, was distinguished by the presence of important visitors including Sir Carruthers Beattie, first Principal and Vice-Chancellor of UCT. On 8 June, Prof Prinz presented a paper, 'Simon Lemnius: A chapter from the history of humanism in Germany'. ${ }^{13}$ The Minute Book notes, "The paper, which gave a lively picture of some characteristic figures of early Reformation days in Germany, was distinguished by the patient research with which the writer had gathered together the little known facts about the life and writing, of Lemnius, and in particular his notorious feud with Martin Luther. Especially interesting for Classical students was the information about Lemnius' much-admired, but now almost unknown, version of the Odyssey in Latin

Oxford, taking up the position of Dean of Divinity at Magdalen College, where he became friendly with the Inklings, and in particular C S Lewis, who recommended him for the position of Professor of Poetry in 1938. He was later appointed as a canon at Westminster Abbey, London, where he remained for the rest of his life. He is buried in Poet's Corner. He published works of poetry, biography, as well as popular studies of Plato. For further biographical details, see Gerold 2001:201-214, who survey's the details of his life, and discusses his publications, demonstrating the influence of Christian Platonism. On his South Africa years, Gerold 2001:203 merely cites an anonymous quotation which stated that 'In later times Fox used to speak of the years at Rondebosch as among the happiest of his life'. A pamphlet, Adam Fox and his association with Bishops, published by John Gardener in 1995 provides more insights into Fox's time in the Cape. He was a much-loved teacher at the school and formed the Literary and Sociological Society (later renamed the 'Ten Club') in 1927, often giving talks on Plato.

12 The paper read by Patrick Duncan (1870-1943) was also published in the first issue of Proceedings and Selected Papers of the Classical Association of South Africa (19271929:23-31). Sir Patrick Duncan, Governor-General of South Africa, received an excellent classical education from his parish school in Scotland. By the age of twelve he was able to read Cicero and Xenophon; later he entered Edinburgh University where he was taught by S H Butcher, Professor of Greek and an expert in Aristotle (perhaps awakening his lifelong interest in Greek philosophy) as well as W Y Sellar, Professor of Latin. From there he progressed to Balliol College, Oxford, on a Warner Exhibition, gaining first class passes in both Mods and Greats. Further biographical notes on Duncan are to be found in Deborah Lavin's edited collection of selected letters between Duncan and Maud Selborne for the Van Riebeek Society (2010:xiv-xxxiv). Duncan's main area of interest within the classical world was Greek philosophy. He published a translation of Plato's Phaedo for Oxford University Press in 1928, as well as articles on Socrates and Plato (Duncan 1940:339-362), the place of art in Plato's ideal state (Duncan 1940:27-38), and the immortality of the soul in Plato's dialogues and Aristotle (Duncan 1942:304-323).

13 Johannes Prinz, for a time married to the celebrated South African artist Irma Stern, was Professor of German at the University of Cape Town until his retirement in 1937 (Phillips 1993:267). 
Hexameters'. Attendance of roughly 20 people is recorded. On 17 August, Dr F Bodmer presented a paper on Johann Joachim Winckelmann, illustrated with lantern slides, assessing his influence on the study of Greek sculpture, while also emphasising the comparative poverty of materials available to him at the time upon which to base his conclusions. ${ }^{14}$ Prof R Nauta gave a lecture on 'Oedipus in the French Classics' at the meeting on 19 September. ${ }^{15}$ The entry records, 'The lecturer dwelt first upon the sympathy between our own age and that of the Athens of the $5^{\text {th }}$ century, as evidenced by the new widespread demand for performances of the Attic Tragedies in complete and faithful translations'. It further notes that the plays of Corneille and Voltaire were discussed as particular examples of the period. The last paper was read on 10 October, by Mr G H Wilson, who selected 'The characters of Theophrastus' as his subject. ${ }^{16}$

14 The Swiss philologist Fredrich Bodmer joined UCT in 1927 as lecturer in the German department and was the author of The loom of language: A guide to foreign languages for the home student (1944), see Phillips 1993:20, 267-8.

15 Renicus Dowe Nauta was Professor of French at UCT until his retirement in 1932. In 1915 he had published a paper in the South African Journal of Science entitled, 'Notes on French Classical tragedy' (Phillips 1993:19, 268).

16 George Hough Wilson (1875-1950) was born on 12 February at the vicarage of St John's Church in Huddersfield, West Yorkshire, in England. His autobiography, Gone down the years (1947:12-29), records his learning of Latin and Greek from his father at a young age, his formal schooling in the subjects at the vicarage in the town, and of being offered a scholarship for study at Peterhouse, Cambridge, which he turned down, to pursue a career in journalism. He began working at the Export Gazette, then in 1894 was offered a better position at Rider Haggard's African Review, before emigrating to the Cape Colony to take up a position at the Cape Times at the end of 1895. It is worth digressing at this point, because of the personalities involved, to relay an anecdote told by Wilson in his autobiography in the context of his reminiscing about Jan Smuts' command of Greek. Wilson records that one night at a dinner at which Smuts was present, someone made mention of lines from George Meredith's 'Ode to France' ('The gods alone / Remember everlastingly and strike / Remorselessly, and ever like for like. / By their great memories the gods are known ...'), to which Smuts interjected that the lines were in fact from Sophocles. Wilson, interested in pursuing the passage in question, later approached UCT's Professor Ritchie, asking him to locate the verses. Ritchie replied that he knew the passage and would send Wilson the reference. Later, the professor had to admit that he had hunted in vain for the passage, even putting his pupils to the task, searching through their Sophocles, in an attempt to find the lines. Wilson recalls that later he found out that the bookseller, Maskew Miller, had sold an amazing run of copies of Sophocles, and indeed, that every copy of Sophocles had been checked out of the National Library. Later, too, when Wilson came upon Professor Haarhoff, who was visiting the Cape at that time, he was told by him that 'one of the most curious things he could recall was the enormous demand for Sophocles from all students of the classics in his year'. Still further, Wilson enlisted the help of the assistant Professor of Classics at Cape Town, Benjamin Farrington, to which he replied, 'Is this the root of this 
The first committee meeting for that year took place at Prof Ritchie's house on 20 June, with Prof Le Roux, Rev A Fox, Mr Munday, and Mr B Farrington present. Dr Rollo was also present, at the invitation of the committee members, owing to his role as Honorary Secretary of the National Association. The Secretary, Mr Farrington, brought forward the proposal that the paper read by Dr Prinz should be accepted for publication, upon terms proposed by Dr Prinz himself, (1) that the paper should be published under the auspices of the Classical Association, (2) that the expense should be borne by Dr Prinz, (3) that the Association should endeavour to secure subscriptions up to the number of 150 at $1 / 6$ each, and that, (4) a special feature of the printed volume was to be the inclusion of some 15 plates reproducing the title pages of Lemnius' published works. The Committee felt that with regard to (1) that it was undesirable that the first publication of the newly-formed Association should be concerned with a subject that fell outside its sphere; with regard to (2) and (3), that the chances of securing 150 subscribers were very small indeed, 150 being about the total membership of the Association; and finally that with regard to (4) that a reproduction of a book of the Odyssey would interest members more than the title pages. The Secretary was instructed to inform Dr Prinz of the Committee's decisions and to discuss that matter further with him. The Committee met next on 10 October, after Mr Wilson's paper, with Prof Ritchie, Rev Fox, Mr Whiteford, and Mr Farrington present. Rev Fox, together with the President, was appointed to attend a meeting of the Central Executive to discuss the proposed visit of the English Classical Association to South Africa in 1930. Mr Farrington reported that he had had discussions with Prof Prinz over the decisions of the Committee about the publication of his paper. He reported that Prof Prinz was willing to include Book VI of the Odyssey, and agreed that the first publication of the Association

amazing search through Sophocles, which has been in progress for weeks? It has been quite unprecedented in the annals of the University, and no one has found the passage yet'. Wilson and Farrington then conspired together to translate the lines of Meredith back into their best Sophoclean Greek. When later Wilson came across Ritchie, he produced the translation to him, to which, Ritchie, after examination, agreed that it was indeed the passage, and asked for the reference; Wilson replied that he had found it in the German collection of Sophoclean fragments. He admits that he was regretful that he had never finally confessed the prank to poor old Professor Ritchie. Some consolation is to be found in the fact that he played the same trick on the Regius Professor of Greek from Cambridge, who was then visiting Cape Town, and who, after examining the lines of verse said, 'that the Greek version was not Sophocles, but that it appeared to him undoubtedly to be Euripides'! Wilson concludes the anecdote by saying that many years later he found the real source of the lines in Homer (1947:67-69). An abbreviated version of this story is also told in an obituary for Ritchie (from which newspaper is not clear) in the folder 'BUZV' in the UCT Special Collections and Archives. 
should be about a strictly classical subject. He still desired, however, that the paper, if published, should appear under the auspices of the Classical Association of South Africa, as one of its publications. Mr Farrington was left to convey the matter with Dr Prinz to the publications committee. Included in the Minute Book at this point is a newspaper clipping from the Cape Times, 9 December 1928, 'Classical lectures in Cape Town. Review of a year's work'. After stating that the average attendance at meetings for the year was around 25 persons, the article attempts to stress the popular appeal of the Cape Town Branch's meetings,

Probably this number does not at all represent the total of those who would be glad to join the Branch, or to avail themselves of the invitation to attend its public lectures, if the nature of its activities and the audience for which it caters were better understood. Though the meetings are, by courtesy of various professors, held in the University, the Branch is not a university society, but a Cape Town society; the lecturers are drawn by no means exclusively from those engaged in the teaching of Classics; the subjects are such as can appeal to any cultured, but not specialist, audience.

The article continues by outlining the various speakers and their topics for the year, but also notes that local branches of the Association did not undertake to publish the lectures delivered before them, but that there was a publications committee for the National Association which chose papers from among those presented at the various meetings deemed worth including in its proceedings. From the Cape Town branch, the article notes, Adam Fox's paper on the place of the New Testament among the Classics along with Patrick Duncan's paper on Plato's doctrine of reality were recommended to the Publications Committee. ${ }^{17}$ The report also quotes William Ritchie's comments in relation to Theophrastus' voluminous output, stating that, 'Mr Wilson had probably even surpassed him in the amount of his writings; certainly his intimate knowledge of varied types of men made him a very happy commentator on the originator of the literary genre that takes abstract analysis of character for its subject'. And in relation to Wilson's classical education and his profession as a journalist, the report continues, 'It also became apparent, not only that the lecturer had an almost life-long intimacy with his subject, but that the acquisition of such an intimacy in youth was no bad preparation for a career that gave one much opportunity to observe the foibles and idiosyncrasies of mankind'.

The first Committee Meeting for 1929 took place on 17 April, in the library of the Diocesan College, Rondebosch, with Ritchie, Le Roux, Fox, Rollo, and

17 The papers by Patrick Duncan and Adam Fox were both published in the Proceedings and Selected Papers of the Classical Association of South Africa, 1927-1929, see above. 
Farrington present. Arrangements were made for the work of the society, and Dr Rollo reported on the proposed visit by the English Classical Association to South Africa. At the first lecture for the year, given on 10 May, Prof Le Roux spoke on 'The palace of Minos', having recently visited Crete, presenting some fifty lantern slides at the lecture. The entry records that it was attended by about 50 people. On 14 June Prof C Edgar, from Stellenbosch, spoke on Menander. The meeting was held in the Fairbridge Library, at the National Library in Cape Town. ${ }^{18}$ An audience of 25 persons was recorded. After the lecture the Annual General Meeting was held, the minutes for 1928 were read and confirmed, the treasurer's statement accepted, and the same committee was re-elected for the following year. On 26 June, Dr W Rollo spoke, again in the Fairbridge Library, on the Pervigilium Veneris, to an audience of about 30 people. On the paper's details, the Minute Book records, 'The lecturer dealt with the literary and linguistic aspects of the poem, and also with its subject matter, in an attempt to fix its date and provenance. On all accounts he inclined to place the poem in the $2^{\text {nd }}$ half of the $4^{\text {th }}$ century $\mathrm{AD}$, and to regard it as a product of pagan revival that centred round Symmachus'. On 21 August, Mr A H J Bourne presented his research on Livy XXI-XXX, paying particular attention to Hasdrubal's march to the Metaurus and to the figure of Sophonisba. The lecture was also held in the Fairbridge Library, and 25 people were present. Summary details of the lecture were reported in the Cape Times, 24 August 1929, a clipping of which is included in the Minute Book. Dr Hugh Smith on 18 September gave a lecture to around 100 people in the Public Library in Cape Town on medicine among the Greeks and Romans of Classical Times. A press clipping for Dr Smith's talk is included, summarising the contents of the talk. No indication of newspaper, or date, is given, but it presumably comes from the Cape Times.

For 1930, Prof P Van Braam of Stellenbosch is recorded as reading a paper in the Fairbridge Library on 4 April on 'The conception of tragedy in Classical Drama'. ${ }^{19}$ Roughly 40 people were present. The Committee which was elected that year had Prof W Ritchie again as President, Mr B Farrington and Mr O Satchel as Honorary Secretaries, Prof T Le Roux as Treasurer, along with Mr E N Munday and Mr R Whiteford as further Committee Members. On 12 May Mr B Farrington gave a talk on Anna Comnena. The meeting was held in the Fairbridge Library and about 35 people were present. Mr O Satchel presented a paper on 'The claims of Latin on South African schools' on 17 June. ${ }^{20}$ Again, the meeting was held in the

18 C S Edgar was the Chair of Greek at Stellenbosch University from 1903-43 (Smuts 1960:26-27).

19 P Van Braam was Professor at Stellenbosch from 1913-46 (Smuts 1960:27-29).

20 Oscar John Soley Satchel was born in Carlisle in Cumberland in England on 25 December 1866. He completed BA and MA degrees in London, coming out to South 
Fairbridge Library, with 30 people attending. Prof T Le Roux lectured on Delphi, with lantern slides, on 27 August. The lecture, to an audience of about 35 people, was held in the Engineering Theatre in the University Buildings, Cape Town. And finally, on 22 October, Dr W Rollo spoke on Roman Britain, illustrating his talk to an audience of 35 people with slides, again in the Engineering Theatre.

At the Committee Meeting in the home of Prof Ritchie, on 27 October, the members decided to print the programme for the upcoming year ahead of time, and the secretary was tasked with organising the following meetings: 1. Wednesday, 18 March, Prof Barnard; 2. Wednesday, 15 April, Prof Edgar (lantern lecture); 3. Friday, 12 June, Annual Meeting of the South African Classical Association. Prof Ritchie to give the Presidential address on 'Latin letter writing and Apollinaris Sidonius'; 4. Wednesday, 12 August, Prof Ryne; 5. Wednesday, 9 September, Dr Viljoen; 6. Wednesday, 14 October, Mr Satchel on Ovid. A stipulation was added that if any of the lecturers fell out, Mr Kidd was to be asked. A copy of the pamphlet produced by the committee with the various details of the lectures, including their titles can be found preserved in the Minute Book.

The programme for 1931 progressed according to the intended plan, with only minor changes. Prof T T Barnard spoke on 'Anthropology and the origins of Western civilization'. ${ }^{21}$ The Minute Book notes that it was held in the Public Library in Cape Town, that Prof Le Roux chaired the session in the absence of

Africa during the Anglo-Boer War. He joined Brabant's Horse and patrolled the Pakhuis Pass, near Clanwilliam. He became ill and was transferred to Walvish Bay, where he met his future wife, Rose, marrying her in 1904. He was then appointed Inspector of Schools in the Vryburg area until 1918, when he was appointed Headmaster at Kimberley Boy's High School. He retired in 1927 to Plumstead in the Cape and took up a temporary post at Bishops, but eventually stayed on for 21 years. He served as chief examiner in Latin for the joint Matriculation Board, and on 30 June 1950, was awarded the honorary degree of Doctor of Literature, at which time Prof William Rollo was Dean of the Faculty of Arts. It is along with Rollo that Satchel is perhaps best known for the production in 1931 of selections from Ovid's Metamorphoses for use in South African schools. In the Preface to the work, Rollo and Satchel mention the help of Prof T Le Roux and thank Prof W Ritchie, stating that 'with a long life's experience as a Professor of Classics in South Africa he may find some pleasure in the fact that the present editors have prepared in South Africa an edition of Ovid's Metamorphoses for South African students'. Satchel died at the age of 87 on 17 October 1953 (information for this brief biography is based upon unpublished papers housed in the archives at the Diocesan College, Rondebosch; see also Moult 1987:86-106, for a published account of his tenure at Kimberley Boys' High School).

21 Thomas Barnard held the chair in Anthropology at UCT from 1926 until 1933 (Phillips 1993:26). 
Prof Ritchie, and that Prof Drennan and Mr Schapera spoke after the lecture. ${ }^{22}$ Prof C Edgar, from Stellenbosch, gave a paper entitled, 'Work and play in earliest Greece' on 22 April in the Arts Block of the University at the Groote Schuur campus, with about 40 people present. On 12 June, the Public Library in Cape Town hosted the joint meetings of the Cape Town Branch and the Annual General Meeting of the Classical Association of South Africa. After the reports of the general secretary and treasurer were given, Prof B Farrington gave a lecture on 'Shelley's translations from the Greek'. Prof T Le Roux acted as chair, as Prof Ritchie was away in Europe. 40 persons were present. The Cape Times of 13 June 1931, reported on the lecture, in an article titled 'Shelley's mental growth', as well as reporting on the growth of the Classical Association of South Africa. ${ }^{23}$ Before the meeting, the Minute Book records that a Committee Meeting was held. Mr O Satchel acted as chair, with Prof Farrington, Prof Le Roux, Dr Rollo, and $\mathrm{Mr}$ Whiteford present. The previous year's minutes were read and confirmed, and the following committee was elected: Prof W Ritchie (President), Mr R Whiteford (Honorary Secretary and Treasurer), Prof Le Roux, Mr O Satchel, and Miss S Lewis as additional members. On 12 August, again in the Public Library in Cape Town, Rev A Fox, now listed as a Fellow of Magdalen College, Oxford, gave a

22 Matthew Robertson Drennan (1885-1965) was Professor of Anatomy at the University of Cape Town from 1919 until his retirement in 1955. Born in Galston, Ayrshire, in the United Kingdom, he completed his schooling in Scotland, taking an MA at the University of Edinburgh in 1907, gaining honours in both classical and modern subjects, along with the George Heriot Classical Bursary among other prizes and scholarships. He published over 70 scientific papers on a range of medical topics and was author of anatomical textbooks. For further information, see his obituary, published in the South African Journal of Science 1966:122-125, along with Phillips 1993:88-90. Isaac Schapera (1905-2003), the son of Jewish immigrants to South Africa from Belarus, was a student of both Bronislaw Malinowski and A R Radcliffe-Brown, educated at SACS, the University of Cape Town, and the London School of Economics. He held positions at both institutions. Radcliffe-Brown was appointed chair in social anthropology at UCT, the first established chair in this subject anywhere within the British Empire (Kuper 2007:21), a department that Schapera later joined after his graduate work at the LSE. In 1950, however, Schapera once again returned to LSE to take up the chair, working there until his retirement in 1969. For classicists, Schapera is best known as editor and translator, along with Benjamin Farrington, of a publication for the Van Riebeek Society, The early Cape Hottentots described in the writings of Olfert Dapper (1668) Willem ten Rhyne (1686) and Johannes Gulielmus de Grevenbroek (Cape Town, 1933). For further details of his life, and his involvement at UCT, see Kuper 2007:19-41 and Phillips 1993:271-275.

23 Farrington had gained his Master's degree from University College, Cork, in 1917 with the thesis, 'Shelley's translations from the Greek'. Further details of his interests in Shelley are to be found in Atkinson 2010:671-692 and esp. Atkinson 2018:376-394. 
lecture on Bentley. ${ }^{24}$ The Minute Book notes that attendance was poor, barely 20 people. On 16 September at the Public Library an address was read by M C Botha, the Superintendent General of Education, on 'The case for the Classics in South Africa'. ${ }^{25}$ Around 35 people were present, and in the absence of Prof Le Roux, Prof Farrington chaired the meeting. At the close of the session, the chairman asked those present to stand in a minute of silence out of respect for the late Prof W Ritchie, and it was resolved that a message of sympathy should be sent to the relatives of Prof Ritchie. ${ }^{26}$ Prof Le Roux was then elected as President of the Cape Town Branch of the Association. The meeting was reported on in both the Cape Argus and Cape Times on 17 September 1931. The Argus carried the title, 'True ideals of education: Professor Botha on the Classics - Mental discipline and character building', in which it explained that Prof Botha defended the subject in the secondary school curriculum against its condemnation by Herbert Spencer, quoting Botha: 'to a great extent the idea of mental and cultural development has been displaced by the idea of efficiency' resultantly placing the Classics option in schools in a precarious position. Botha was further quoted as saying, 'Football, the bioscope, dance music and detective stories seem to have become the chief cultural ambitions of South Africans' and that it 'was a waste of time to teach a subject like Latin to weaker students ... the student who could do neither mathematics nor Latin was not fit to go to the university for a literary or scientific course. Those who could learn it, should take Latin in school. Modern languages could always be learnt at a later stage'. The article ends with Botha being quoted as claiming that 'Classics will always be studied ... if for no other reason, because the languages of Europe cannot be studied without reference to Rome and Athens ... I often wonder', the quotation continues, 'if the complaints about slovenly English and Afrikaans in our schools may not be accounted for by the way in which we have allowed Latin to be displaced by other subjects'. The Cape Times reported along similar lines under the headline, 'After-school culture, jazz, detective fiction and rugby: Prof M C Botha's onslaught'.

On 21 October, in the Public Library, Cape Town, a lecture was given by O J S Satchel on Ovid, with about 50 people in attendance. After the lecture, a

24 Fox was later to publish John Mill \& Richard Bentley: A study of the textual criticism of the New Testament 1675-1729 (Oxford, 1954).

25 M C Botha, formerly lecturer and later chair in Nederlands and Afrikaans literature at UCT, played an important role in the development of the Afrikaans language as a university subject, also producing a number of textbooks (Phillips 1993:18-9).

26 En route to South Africa from a visit to England, William Ritchie stopped at Entebbe, Uganda, in order to visit his daughter, Mrs V Forrest. He died there in September 1931 from a heart-attack (see Van der Merwe 1929-1931:4-5 for an obituary, as well as notes and newspaper cuttings in the 'BUZV' folder in UCT Special Collections). 
meeting of the committee was held in which it was decided that the Classical Association should assume responsibility for the Reading Circle, which had been formed at the suggestion of Miss Rowe, and that Prof Farrington was to supervise it - all this on condition that members of the Reading Circle would also become members of CASA.

The first meeting recorded for 1932 took place on 1 June, with Prof Le Roux speaking to approximately 130 people on the topic of 'Greek athletics and the Olympian Games'. It was illustrated with lantern slides. On 29 June, Prof J Kerr Wylie, from the Law Department of the University, gave what is recorded as a 'controversial' paper on the 'Teaching of Roman history' to an audience of about 25 people. ${ }^{27}$ On 12 October, with 20 people in attendance, Mr A H J Bourne read a paper in the hall of the Public Library on 'The Philippics of Cicero'. The Minute Book also records that during the month of August of that year, Prof Farrington, under the auspices of UCT, held four extension lectures on Plato. The Classical Association, therefore, decided against holding a meeting in that month.

The opening lecture of the year 1933 was given by Prof Farrington to an audience of about 100 people. The topic of the talk was 'Horses and slaves in Antiquity', given in response, the record notes, to the book, L'attelage, le cheval de selle à travers les âges (Paris, 1931). The lecture was illustrated with lantern slides reproduced from the book. On 7 June, Dr W Rollo gave a lecture in the Public Library on 'Ostia: The story of Rome's harbour'. It too was illustrated with lantern slides, and about 80 people were in the audience. Dr F Bodmer gave a lecture, on 30 August in the Fairbridge Library, entitled, 'From Aristotle to Lessing: Some reflections on the social basis of the drama' with 30 people in attendance. Under the auspices of the Branch, on 11 November, Miss I M E Freemantle produced Sophocles' Antigone in the Hiddingh Hall with a large audience of more than 200 people attending. ${ }^{28}$

With roughly 40 people in attendance, Prof B Farrington gave the following lecture on 16 May 1934, 'The city of the sun: The Stoic Utopia'. On 21 September, Miss M Ferguson of Huguenot University College, Wellington, read a paper on 'The heroic age'. The Minute Book records that 'owing to the fact that several other meetings were being held on the same evening, the number of those present was small'. On 24 October, Mr O J S Satchel, having recently returned from a trip to Greece, gave a lecture on 'A pilgrim in Greece: Reflections' to an audience of about 50 people. The Minute Book also records for that year a meeting arranged by

27 John Kerr Wylie was Chair of Roman Law and Jurisprudence at UCT from 1924-48 (see Phillips 1993:68).

28 For further details on the classical activities at Huguenot College, Wellington, as well as further biography of Isabella Freemantle and her colleague, Margaret Ferguson, mentioned below, see Murray 2014:105-126. 
the Secretary of CASA on 24 August, held under the joint auspices of the Cape Town Branch and the English Association. Dr W Boyd from the University of Glasgow, who was visiting South Africa in connection with the NEF Conferences held in both Cape Town and Johannesburg, addressed a hall (packed to capacity) on the subject of 'Literature, ancient and modern, in South African education'. ${ }^{29}$ Prof T Le Roux was in the Chair.

The notes in the Minute Book for the following two years are meagre, with only two meetings recorded for each year. On 17 April 1935, Mr C Manolas gave a paper on modern Greece as it was at that time, with a large audience, including the Consul for Greece, and on 7 August, Dr F Bodmer read a paper, but no title is given. The record does indicate an attendance of some 25 people. For 1936, Prof W Rollo is recorded as giving a lecture on 'Nationalism and internationalism in the Ancient world', with no date given, nor a record of attendance, and the second meeting for the year is recorded as given by Miss M Clarke on 'The Greek leagues'.

In 1937 the record picks up again, noting a paper read by Mr H C Baldry on 14 April, on 'War and peace in Euripides' in the Fairbridge Room, before an audience of 23 people. ${ }^{30}$ On 18 June, Prof A M Young, of Huguenot University College, read a paper on 'Lucan as historian' in front of an audience of 16 people, again in the Fairbridge Room. ${ }^{31}$ In the hall of the Public Library, on 1 September, the Professor of Architecture at the University of Cape Town, Thornton White, delivered an address on 'The lessons of Classical architecture for the modern architect' to an audience of about 70 people. ${ }^{32}$ The lecture was illustrated by lantern slides. The Minute Book also records for October of that year the University Extension lectures given by Prof $\mathrm{W}$ Rollo on 'Modern problems in the ancient world'.

On 17 August 1938, a meeting was held with 18 people in attendance in the Fairbridge Room of the Public Library, with Prof W Rollo in the Chair. The

29 William Boyd (1874-1962) was Reader in Education at Glasgow University.

30 Harold Caparne Baldry (1907-1991) came to UCT in 1936, having studied Classics at Trinity Hall, Cambridge. He was promoted to professor in 1949 and delivered an inaugural address on 'The Classics in the modern world'. He left Cape Town in 1954 to take up the chair in Classics at the University of Southampton (see Smuts 1960:22 and Atkinson 2014:170-184).

31 Annie Mary Young (1890-1962) was lecturer in Classics at Huguenot College, Wellington. She studied Classics at Girton College, Cambridge, had an LLB from the University of London, and had held several posts in England and New Zealand before coming to South Africa (Murray 2014:122).

32 Leonard William Thornton White (1901-1965) was the first Professor of Architecture at UCT, who joined the university in 1937, after studying at London University and the British School in Rome (see Phillips 1993:310-13). 
audience stood for a minute of silence to show its sympathy for Mr Satchel in light of a recent bereavement. Mr P T Stevens, Lecturer in Classics at the University of Cape Town, read a paper on 'Literature in Utopia: Plato and the poets'. ${ }^{33}$ The record notes that Prof Edgar expressed the hope that Mr Stevens would publish the paper. On 21 September, Prof Goodlet of the University of Cape Town lectured on 'Armaments in the ancient world' which he illustrated with working models. ${ }^{34}$

For 1939 only one meeting is recorded. It was held on 16 August in the Lecture Theatre of the Arts Block, University Buildings Groote Schuur at 12:40pm, with Prof Le Roux in the chair. About 200 people were present, and Prof H E Sigerist of Johns Hopkins University gave a lecture on 'Greek medicine'. ${ }^{35}$ The Cape Times of 17 August reported on the event in a short article under the title of 'Medicine in Ancient Greece'.

33 Philip Theodore Stevens (1906-1992) graduated BA from New College, Oxford in 1929, followed by several appointments: Assistant Master at Liverpool Institute, Tutor at the University Correspondence College, Cambridge, Assistant Lecturer in Greek at Aberdeen (where he graduated with a $\mathrm{PhD}$ in 1939), Lecturer in Classics at the University of Cape Town (1938-41), war service in Military Intelligence in Pretoria, Lecturer in Greek at Liverpool, and finally Professor of Greek at Bedford College, London. He worked mainly on Greek literature, and especially drama. See further, his entry in The dictionary of British Classicists, 1500-1960 Vol. 3 (2004:924-5). Brain Goodlet was Professor of Electrical Engineering at UCT, having arrived at the university in 1937 (Phillips 1993:299-301).

35 Henry Ernest Sigerist (1891-1957) was a Swiss-born medical historian and director of the institute for the history of medicine at Johns Hopkins University at the time of his visit to the Cape, which he recounts in Sigerist 1940:22-27. Of Cape Town, he writes, 'I spent five weeks in Cape Town where I gave a course of lectures at the University, and I am sure everybody will agree that no institution of learning in the world has a more beautiful site than the University of Cape Town' (Sigerist 1940:22). It appears that Sigerist was acquainted with Benjamin Farrington before his visit to Cape Town (although Farrington was no longer based at the university, having left in 1935); a letter from the British historian of science, Charles Singer to Sigerist, dated 9 January 1935, records the following: 'Farrington is, I think, going to settle in England for a year or two. He is a quiet industrious worker \& is dissatisfied with Cape Town. I rather think that he means to undertake a major piece of research before looking for another post. (He is professor of classics \& is a product of Trinity College, Dublin.) I need hardly say that I would help him or you or both of you in this matter in any way in my power. My only desire is to see the table [?] brought to a satisfactory conclusion. Do let me hear how you [....] as regards Vesalius \& what you would like me to do with the Nonesuch \& with Farrington' (this transcription of the letter is published in Bickel 2011:159). Farrington produced partial translations of Andreas Vesalius' De fabrica corporis humani, 1543 (see Atkinson 2010:689), in the preface of which he thanked Charles Singer. 
The final entry in the Minute Book records a meeting on 22 April 1940. The meeting was held at the Little Theatre at $8: 15 \mathrm{pm}$, with Prof Le Roux in the chair, and roughly 200 people in the audience. The record notes that his Excellency, the Governor General, Sir Patrick Duncan gave an address on 'The place of art in Plato's Ideal State'. A vote of thanks was given by Mr O Satchel, and seconded by Professor Falconer, Principal of the University of Cape Town. The meeting was again reported on by the Cape Times, 23 April, in a short piece under the title, 'Sir Patrick Duncan on Plato'.

In his history of the University of Cape Town for the years 1918-1948, Howard Phillips provides a rather damning summation of the activities of the Classics Department of that time. He writes,

Certainly the syllabus in the Classics Department in these years remained an unvarying mix of setworks, unseens, prose composition and ancient history; no effort was made to address the particular problems of South African undergraduates or to provide for the peculiar needs of Law students who made up the bulk of those taking Latin. Even the presence in the department of such innovative minds as Benjamin Farrington and William Rollo (both senior lecturers who later became professors at UCT) made little impact on what was taught. ${ }^{36}$

A quick perusal of the Minute Book for these years, however, presents a somewhat different perspective. The Cape Town Branch of the Classical Association was providing extra-mural activities for staff, students, and the public alike — offering talks at a range of levels, for a variety of interests. Subjects for papers ranged from the purely classical, to the interaction of the classical and Christian worlds, as well as the influence of the ancient world on modern society, literature, philosophy, education, and architecture (what today might in part be termed 'Classical Reception Studies'); indeed, it appears as if even inter-disciplinary contacts were made between Classics and Social Anthropology (a department newly established, as stated above, and the first of its kind anywhere in the British Empire). It was involved in the public productions of classical drama, and not only were strong links fostered between the schools and university, but the Branch also took advantage of visiting lecturers, and enjoyed the involvement of important members of South African society at the time. Where a gap could be seen in the activities as presented in the Minute Book is in regard to the Branch's wartime efforts. The only clue that any intellectual energy at all was spent on topics of global importance are the titles of papers given by William Rollo in 1935, 'Nationalism

36 Phillips 1993:15. 
and internationalism in the ancient world' and in 1937 by H C Baldry on 'War and peace in Euripides'.

Maurice Pope's recently published autobiography, Amateur (2018), picks up the narrative of Cape Town Classics almost a decade later, from 1949 when he joined the University. It provides personal reflections on the workings of the department and figures such as Harold Baldry, Jean Ballantyne, Leslie Burrows, Philippa Forder, George Goold, Hansell Hewitt, Anton Paap, and William Rollo, up until his own (Pope's) resignation over the Archie Mafeje affair in 1968. ${ }^{37}$

\section{BIBLIOGRAPHY}

Atkinson, J 2010. Benjamin Farrington: Cape Town and the shaping of a public intellectual. South African Historical Journal 62:671-692.

2014. Alexander and the unity of mankind: Some Cape Town perspectives. In Bosman, P (ed.), Alexander in Africa, AClass Supplementum V, 170-184. Pretoria: V\&R Printing Works.

2018. Benjamin Farrington and the science of the swerve. In Parker, G (ed.), South Africa, Greece, Rome: Classical confrontations, 376-394. Cambridge: Cambridge University Press.

Baumbach, L 1987. In Memoriam: Robin Whiteford. Akroterion 32:48.

Bickel, M H (ed.) 2011. Correspondence: Henry E Sigerist - Charles Singer 1920-1956, Medical History Supplement 30. London: The Wellcome Trust Centre for the History of Medicine at UCL.

Bodmer, F 1944. The loom of languages: A guide to foreign languages for the home student. London: George Allen \& Unwin.

Duncan, P 1927-1929. The Platonic doctrine of reality. Proceedings and Selected Papers of the Classical Association of South Africa, 1:23-31.

1928. The Phaedo of Plato. Oxford: Oxford University Press.

1940. The place of art in Plato's ideal state. University of Toronto Quarterly 10:27-38.

1940. Socrates and Plato. Philosophy 15:339-362.

1942. Immortality of the soul in the Platonic dialogues and Aristotle. Philosophy 17:304-323.

Editor 1966. Obituary: Professor Matthew Robertson Drennan (1885-1965). South African Journal of Science 62:122-125.

Eggermont-Molenaa, M 2009. Marquina 1923: Student Rollo and his wife among the Basques. Cape Town: Professor Rollo and his wife among the SouthAfricans. Euskera 54:307-342.

37 On the Mafeje affair, see Hendricks 2008:423-451. 
Hendricks, F 2008. The Mafeje affair: The University of Cape Town and Apartheid. African Studies 67:423-451.

Fox, A 1927-1929. The New Testament and its place among the Classics. Proceedings and Selected Papers of the Classical Association of South Africa, 1:31-42.

1954. John Mill \& Richard Bentley: A study of the textual criticism of the New Testament, 1675-1729. Oxford: Basil Blackwell.

Gardener, J 1995. Adam Fox and his association with Bishops. Rondebosch: OD Union.

Gerold, T 2001. Adam Fox (1883-1977): Dichter und christlicher Platoniker. Inklings-Jahrbuch 19:201-214.

Henderson, W J 2013. The Classical Association of South Africa, 1908-1956. Akroterion 58:123-150.

Kuper, A 2007. Isaac Schapera (1905-2003): His life and times. In Comaroff, J L, Comaroff, J \& James, D (eds.), Picturing a colonial past: The African photographs of Isaac Schapera, 19-41. Chicago/London: University of Chicago Press.

Lavin, D 2010. Friendship and union: The South African letters of Patrick Duncan and Maud Selborne, 1907-1943. Cape Town: Van Riebeeck Society for the Publication of Southern African Historical Documents.

Moult, L 1987. K-H Story: A history of Kimberley Boys' High School. Kimberley: Kimberley Boys' High School Centenary Committee.

Murray, J 2014. These are our jewels: Women and Classical education at Huguenot College. AClass 57:105-126.

Phillips, H 1993. The University of Cape Town 1918-1948: The formative years. Cape Town: University of Cape Town Press.

Pope, M W M 2018. Amateur. Mexico City/Brussels: Macizo Ediciones.

Ritchie, W 1918. The history of the South African College, 1829-1918. 2 vols. Cape Town: T Maskew Miller.

Ritchie, W 1927. The plays of Terence: Translated into parallel English metres. London: G Bell \& Sons.

Rollo, W \& Satchel, O J S 1931. Ovid's Metamorphoses: A selection. Cape Town/Johannesburg: Juta \& Co.

Sigerist, H E 1940. A physician's impression of South Africa. Bulletin of the History of Medicine 8:22-27.

Smuts, F 1960. Classical scholarship and the teaching of Classics at Cape Town and Stellenbosch. AClass 3:7-31.

Todd, R B (ed.) 2004. The dictionary of British classicists, 1500-1960. Bristol: Thoemmes Continuum. 
Van der Merwe, A J 1929-1931. In Memoriam: Professor Ritchie. Proceedings and Selected Papers of the Classical Association of South Africa, Second Issue: 4-5.

Wilson, G H 1947. Gone down the years. London: George Allen \& Unwin. 